\title{
Selectivity improvement of an azole inhibitor of CYP707A by replacing the monosubstituted azole with a disubstituted azole
}

Yasushi Todoroki, ${ }^{\mathrm{a}, *}$ Kumi Naiki, ${ }^{\mathrm{a}}$ Hikaru Aoyama, ${ }^{\mathrm{a}}$ Minaho Shirakura, ${ }^{\mathrm{a}}$ Kotomi Ueno, ${ }^{\mathrm{b}}$ Masaharu Mizutani, ${ }^{b}$ Nobuhiro Hirai ${ }^{\mathrm{c}}$

\section{Supplementary data}

The synthetic procedure for new compounds, their ${ }^{1} \mathrm{H}$ NMR and high-resolution MS data, and the procedures for homology modeling, enzyme assay, and biological assays 


\section{General}

${ }^{1} \mathrm{H}$ NMR spectra were recorded with tetramethylsilane as the internal standard using a JEOL JNM-EX270 (270 MHz) NMR spectrometer. High resolution mass spectra (HRMS) were obtained with a JEOL JMS-T100LC "AccuTOF".

\section{2. (E)-1-(1-(4-chlorophenyl)-3-methoxy-4,4-dimethylpent-1-en-2-yl)-5-(methoxymethyl)-1H- imidazole (DSI-503)}

$\mathrm{NaH}$ (60\% in oil, $20 \mathrm{mg}, 510 \mu \mathrm{mol})$ was added to a stirred solution of DSI-501 ${ }^{12}$ (10 mg, $\left.31 \mu \mathrm{mol}\right)$ in dry DMF (2 mL) at $0{ }^{\circ} \mathrm{C}$ under Ar. Methyl iodide $(120 \mu \mathrm{L}, 1.9 \mathrm{mmol})$ was then added to the mixture at $0{ }^{\circ} \mathrm{C}$, and stirred for $2 \mathrm{~h}$ at the same temperature. After being quenched with sat. $\mathrm{NH}_{4} \mathrm{Cl}$, the resulting mixture was extracted with EtOAc $(25 \mathrm{~mL} \times 3)$. The organic layer was washed with $\mathrm{H}_{2} \mathrm{O}$, dried over $\mathrm{Na}_{2} \mathrm{SO}_{4}$, and concentrated in vacuo. The residual oil was purified by silica gel column chromatography with $2 \% \mathrm{MeOH}$ in $\mathrm{CHCl}_{3}$ to obtain DSI-503 (2.4 mg, $6.9 \mu \mathrm{mol}, 22 \%$ ) as colorless oil. ${ }^{1} \mathrm{H}$ NMR (270 MHz, $\mathrm{CDCl}_{3}$ ): $\delta 0.72$ (9H, s, t-butyl), 3.33 and 3.36 (each 3H, s, OMe), $3.39(1 \mathrm{H}$, s, H-3), 4.45 and 4.51 (1H, d, $J=12.5$ Hz, MeO-CH2-5"), 7.13 and 7.15 (each 1H, s, H-1 and H-4"), 7.24 (2H, m, H-2' and H-6'), 7.39 (2H, m, H-3' and H-5'), 7.90 (1H, s, H-2"); UV $\lambda_{\max }(\mathrm{MeOH}) \mathrm{nm}$ (ع): 247.8 (13,300); HRMS (ESI-TOF, positive): calcd for $\mathrm{C}_{19} \mathrm{H}_{26} \mathrm{ClN}_{2} \mathrm{O}_{2}[\mathrm{M}+\mathrm{H}]^{+} 349.1683$, found 349.1695.

\section{3. (E)-1-(1-(4-chlorophenyl)-3-ethoxy-4,4-dimethylpent-1-en-2-yl)-5-(ethoxymethyl)-1H- imidazole (DSI-504)}

$\mathrm{NaH}$ (60\% in oil, $22 \mathrm{mg}, 560 \mu \mathrm{mol})$ was added to a stirred solution of DSI-501 ${ }^{12}$ (10 mg, $\left.31 \mu \mathrm{mol}\right)$ in dry DMF (2 mL) at $0{ }^{\circ} \mathrm{C}$ under Ar. Ethyl iodide $(120 \mu \mathrm{L}, 1.5 \mathrm{mmol})$ was then added to the mixture at $0{ }^{\circ} \mathrm{C}$, and stirred for $1 \mathrm{~h}$ at the same temperature. After being quenched with sat. $\mathrm{NH}_{4} \mathrm{Cl}$, the resulting mixture was extracted with EtOAc $(25 \mathrm{~mL} \times 3)$. The organic layer was washed with $\mathrm{H}_{2} \mathrm{O}$, dried over $\mathrm{Na}_{2} \mathrm{SO}_{4}$, and concentrated in vacuo. The residual oil was purified by silica gel column chromatography with $2 \% \mathrm{MeOH}$ in $\mathrm{CHCl}_{3}$ to obtain DSI-504 (10.2 mg, $27 \mu \mathrm{mol}, 87 \%$ ) as colorless oil. ${ }^{1} \mathrm{H}$ NMR (270 MHz, $\mathrm{CDCl}_{3}$ ): $\delta 0.73$ (9H, s, t-butyl), 1.17 and 1.20 (each $3 \mathrm{H}, \mathrm{t}, J=6.9 \mathrm{~Hz}$, $\mathrm{CH}_{3}-\mathrm{CH}_{2}-\mathrm{O}-$ ), 3.24, 3.46, 3.56 and 3.73 (each $1 \mathrm{H}, \mathrm{dq}, J=9.2$ and $6.9 \mathrm{~Hz}, \mathrm{CH}_{3}-\mathrm{CH}_{2}-\mathrm{O}-$ ), 4.02 (1H, s, H-3), 4.41 and 4.56 (1H, d, $J=12.2 \mathrm{~Hz}$, EtO-CH2-5"), 7.13 and 7.15 (each $1 \mathrm{H}, \mathrm{s}, \mathrm{H}-1$ and H-4"), 7.23 (2H, m, H-2' and H-6'), 7.38 (2H, m, H-3' and H-5'), 7.97 (1H, s, H-2"); UV $\lambda_{\max }(\mathrm{MeOH}) \mathrm{nm}$ (ع): 249.6 (10,900); HRMS (ESI-TOF, positive): calcd for $\mathrm{C}_{21} \mathrm{H}_{30} \mathrm{ClN}_{2} \mathrm{O}_{2}[\mathrm{M}+\mathrm{H}]^{+} 377.1996$, found 377.1992. 
Bis(2,2,2-trifluoroethyl)(methoxycarbonylmethyl)phosphonate (9 $\mu \mathrm{L}, 19 \mu \mathrm{mol})$ was added to a stirred suspension of $\mathrm{NaH}$ (60\% in oil, $1.5 \mathrm{mg}, 40 \mu \mathrm{mol})$ in dry THF (3 mL) at $0{ }^{\circ} \mathrm{C}$ under $\mathrm{Ar}$, and stirred for $1 \mathrm{~h}$ at the same temperature. DSI-502 (5.0 mg, $16 \mu \mathrm{mol})$ in dry THF $(0.5 \mathrm{~mL})$ was added to the mixture at $0{ }^{\circ} \mathrm{C}$. The reaction mixture was stirred for $2 \mathrm{~h}$ at room temperature, and then for $3 \mathrm{~h}$ at $75{ }^{\circ} \mathrm{C}$. After being quenched with sat. $\mathrm{NH}_{4} \mathrm{Cl}$, the resulting mixture was extracted with EtOAc (25 $\mathrm{mL} \times 3$ ). The organic layer was washed with $\mathrm{H}_{2} \mathrm{O}$, dried over $\mathrm{Na}_{2} \mathrm{SO}_{4}$, and concentrated in vacuo. The residual oil was purified by silica gel column chromatography with $2 \% \mathrm{MeOH}$ in $\mathrm{CHCl}_{3}$ to obtain DSI-504MZ (0.5 mg, $1.3 \mu \mathrm{mol}, 8 \%$ ) as colorless oil. ${ }^{1} \mathrm{H} \mathrm{NMR}\left(270 \mathrm{MHz}, \mathrm{CDCl}_{3}\right)$ : $\delta 0.74(9 \mathrm{H}$, s, $t$-butyl), $3.72\left(3 \mathrm{H}, \mathrm{s}, \mathrm{CH}_{3} \mathrm{O}_{2} \mathrm{C}-\right.$ ), $4.57(1 \mathrm{H}, \mathrm{s} \mathrm{H}-3), 5.85$ and 6.89 (each $1 \mathrm{H}, \mathrm{d}, J=12.9 \mathrm{~Hz}$, -CH=CH-5"), 6.65 (1H, s, H-1), 7.23 (2H, m, H-2' and H-6'), 7.35 (2H, m, H-3' and H-5'), 8.07 (1H, s, H-4"), 8.43 (1H, s, H-2"); UV $\lambda_{\max }(\mathrm{MeOH}) \mathrm{nm}(\varepsilon): 251.8$ (9,700), 300.0 (9,100); HRMS (ESI-TOF, positive): calcd for $\mathrm{C}_{20} \mathrm{H}_{24} \mathrm{ClN}_{2} \mathrm{O}_{3}[\mathrm{M}+\mathrm{H}]^{+}$375.1475, found 375.1469.

\section{5. (E)-methyl 3-(1-((E)-1-(4-chlorophenyl)-3-hydroxy-4,4-dimethylpent-1-en-2-yl)-1H-imidazol-} 5-yl)acrylate (DSI-505ME) and 3-(1-((E)-1-(4-chlorophenyl)-3-hydroxy-4,4-dimethylpent-1-en2-yl)-1H-imidazol-5-yl)acrylic acid (DSI-505)

Bis(2,2,2-trifluoroethyl)(methoxycarbonylmethyl)phosphonate (20 $\mu \mathrm{L}, 42 \mu \mathrm{mol})$ was added to a stirred suspension of $\mathrm{NaH}(60 \%$ in oil, $4.5 \mathrm{mg}, 110 \mu \mathrm{mol})$ in dry $\mathrm{THF}(3 \mathrm{~mL})$ at $0{ }^{\circ} \mathrm{C}$ under $\mathrm{Ar}$, and stirred for $1 \mathrm{~h}$ at the same temperature. DSI-502 (12.7 mg, $34 \mu \mathrm{mol})$ in dry THF ( $1 \mathrm{~mL})$ was added to the mixture at $0{ }^{\circ} \mathrm{C}$. The reaction mixture was stirred for $6 \mathrm{~h}$ at room temperature. After being quenched with sat. $\mathrm{NH}_{4} \mathrm{Cl}$, the resulting mixture was extracted with EtOAc $(40 \mathrm{~mL} \times 3)$. The organic layer was washed with $\mathrm{H}_{2} \mathrm{O}$, dried over $\mathrm{Na}_{2} \mathrm{SO}_{4}$, and concentrated in vacuo. The residual oil was purified by silica gel column chromatography with $2 \% \mathrm{MeOH}$ in $\mathrm{CHCl}_{3}$ to obtain DSI-504ME (3.9 mg, $10 \mu \mathrm{mol}, 32 \%$ ) and DSI-505 (Z/E mixture (1:2, estimated by integral ratio of $\mathrm{H}-3$ ), $0.8 \mathrm{mg}, 2.2$ $\mu \mathrm{mol}, 6 \%$ ), as colorless oils. DSI-505ME: ${ }^{1} \mathrm{H}$ NMR (270 MHz, $\mathrm{CDCl}_{3}$ ): $\delta 0.74$ (9H, s, $t$-butyl), 3.80 (3H, s, $\mathrm{CH}_{3} \mathrm{O}_{2} \mathrm{C}-$ ), 4.56 (1H, s H-3), 6.39 and 7.72 (each $\left.1 \mathrm{H}, \mathrm{d}, J=16.2 \mathrm{~Hz},-\mathrm{CH}=\mathrm{CH}-5 "\right), 6.66(1 \mathrm{H}$, s, H-1), 7.31 (2H, m, H-2' and H-6'), 7.42 (2H, m, H-3' and H-5'), 7.59 and 8.11 (each 1H, s, H-2" and H-4"); UV $\lambda_{\max }(\mathrm{MeOH}) \mathrm{nm}(\varepsilon)$ : 251.8 (9,700), 300.0 (9,100); HRMS (ESI-TOF, positive): calcd for $\mathrm{C}_{20} \mathrm{H}_{24} \mathrm{ClN}_{2} \mathrm{O}_{3}[\mathrm{M}+\mathrm{H}]^{+}$375.1475, found 375.1469. DSI-505: ${ }^{1} \mathrm{H}$ NMR (270 MHz, $\mathrm{CDCl}_{3}$ ) of the E-isomer: $\delta 0.67$ (9H, s, t-butyl), $3.64(1 \mathrm{H}, \mathrm{s}, \mathbf{H O}-3), 4.98(1 \mathrm{H}, \mathrm{s} \mathrm{H}-3), 6.79(1 \mathrm{H}, \mathrm{s}, \mathrm{H}-1), 6.92$ (1H, s, H-4"), 7.2-7.3 (overlapped, -CH=CH-5", H-2', H-3', H-5' and H-6'), 7.96 (1H, s, H-2"); ${ }^{1} \mathrm{H}$ NMR (270 MHz, $\mathrm{CDCl}_{3}$ ) of the Z-isomer: $\delta 0.53(9 \mathrm{H}, \mathrm{s}, t$-butyl), $3.49(1 \mathrm{H}, \mathrm{s}, \mathbf{H O}-3), 4.96(1 \mathrm{H}, \mathrm{s}$ H-3), 6.91 (1H, s, H-1), 6.92 (1H, s, H-4"), 7.2-7.3 (overlapped, -CH=CH-5", H-2', H-3', H-5' and 
H-6'), 7.77 (1H, s, H-2"); HRMS (ESI-TOF, positive): calcd for $\mathrm{C}_{19} \mathrm{H}_{22} \mathrm{ClN}_{2} \mathrm{O}_{3}[\mathrm{M}+\mathrm{H}]^{+} 361.1319$, found 361.1308 .

\section{Homology modeling}

CYP707A3 model. Thirty 3D-models of the CYP707A3 protein were constructed using Modeller 8v2. The atomic coordinates of the crystal structure of CYP3A4 (1TQN) were used as a template. The first 34 residues of the $\mathrm{N}$-terminus, which is the membrane anchor region, were not constructed. After adding hydrogens and manually docking $S-(+)-\mathrm{ABA}$, whose geometry was optimized at the B3LYP/6-31G(d) level of theory, the CYP707A3-ABA complex was minimized using the Tinker program with amber99 and modified amber_gaff parameters.

CYP701A3 model. Ten 3D-models of the CYP707A3 protein were constructed using Modeller 8v2. The atomic coordinates of the crystal structure of CYP2C8 (1PQ2) were used as a template. The first 41 residues of the $\mathrm{N}$-terminus, which is the membrane anchor region, were not constructed. After adding hydrogens and manually docking ent-kaurene, whose geometry was optimized at the B3LYP/6-31G(d) level of theory, the CYP701A3-ent-kaurene complex was minimized using the Tinker program with amber99 and modified amber_gaff parameters.

\section{Enzyme assay}

CYP707A3 microsomes. A truncated Arabidopsis CYP707A3 (707A3d28), which lacked the putative membrane-spanning segment of the N-terminus (residues 3-28) was constructed. Cells of E. coli strain BL21 were transformed with pCW-CYP707A3d28 and pACYC-ATR2 constructs. Cultures (3 $\mathrm{mL})$ were grown overnight in Luria-Bertani medium supplemented with ampicillin $\left(50 \mu \mathrm{g} \mathrm{mL}^{-1}\right)$ and chloramphenicol $\left(100 \mu \mathrm{g} \mathrm{mL}{ }^{-1}\right)$. Then, $50 \mathrm{~mL}$ of Terrific Broth medium supplemented with ampicillin (50 $\left.\mu \mathrm{g} \mathrm{mL}^{-1}\right)$, chloramphenicol (100 $\mathrm{g} \mathrm{mL}^{-1}$ ), and aminolevulic acid (0.5 mM) was inoculated with a $0.5-\mathrm{mL}$ aliquot of the overnight culture. The culture was incubated at $37{ }^{\circ} \mathrm{C}$ with gentle shaking (225 rpm) until the $\mathrm{A}_{600}$ reached 0.6 (after 2.5-3 h), and then expression of the P450 enzyme was induced by the addition of isopropyl- $\beta$-D-thiogalactopyranoside $(0.1 \mathrm{mM})$. The culture was shaken continuously (150 rpm) at $25^{\circ} \mathrm{C}$ and cells were harvested $48 \mathrm{~h}$ later by centrifugation at 2,330 $\mathrm{g}$ for $20 \mathrm{~min}$ at $4{ }^{\circ} \mathrm{C}$. Pelleted cells were suspended in $2.5 \mathrm{~mL}$ of a $50 \mathrm{mM}$ potassium phosphate buffer (pH 7.25) containing 20\% glycerol, $1 \mathrm{mM}$ EDTA, and $0.1 \mathrm{mM}$ dithiothreitol. The suspension was sonicated for $30 \mathrm{~s}$, centrifuged at 23,470 $\mathrm{g}$ for $30 \mathrm{~min}$ at $4{ }^{\circ} \mathrm{C}$, and the supernatant (enzyme solution) was collected. The P450 content was determined by spectrophotometric analysis using the extinction coefficient of a reduced CO difference spectrum $\left(91.1 \mathrm{mM}^{-1} \mathrm{~cm}^{-1}\right)$. 
Kinetic analysis. A reaction mixture containing $25 \mu \mathrm{g} \mathrm{mL} \mathrm{m}^{-1}$ CYP707A3 microsomes coexpressed with ATR2 in E. coli, (+)-ABA (final conc.: 1-64 $\mu \mathrm{M}$ ), inhibitors (100-750 nM in $5 \mu \mathrm{L}$ DMF) and $50 \mu \mathrm{M}$ NADPH in $100 \mathrm{mM}$ potassium phosphate buffer ( $\mathrm{pH}$ 7.25) were incubated for $10 \mathrm{~min}$ at $30{ }^{\circ} \mathrm{C}$; controls contained no inhibitor. Reactions were initiated by adding NADPH, and stopped by addition of $25 \mu \mathrm{L}$ of $1 \mathrm{M} \mathrm{NaOH}$. The reaction mixtures were acidified with $50 \mu \mathrm{L}$ of $1 \mathrm{M} \mathrm{HCl}$. To extract the reaction products, the mixtures were loaded onto Oasis HLB cartridges $(1 \mathrm{~mL}, 30 \mathrm{mg}$; Waters) and washed with $1 \mathrm{~mL}$ of $10 \% \mathrm{MeOH}$ in a solution containing $1 \% \mathrm{AcOH}$. The enzyme products were then eluted with $1 \mathrm{~mL}$ of $\mathrm{MeOH}$ containing $0.5 \% \mathrm{AcOH}$, and the eluate was concentrated in vacuo. The dried sample was dissolved in $50 \mu \mathrm{L}$ of $\mathrm{MeOH}$, and $20 \mu \mathrm{L}$ was subjected to HPLC. HPLC conditions were: ODS column, Hydrosphere C18 $(150 \times 6.0 \mathrm{~mm}$, YMC); solvent, $20 \% \mathrm{MeCN}$ in $\mathrm{H}_{2} \mathrm{O}$ containing $0.1 \% \mathrm{AcOH}$; flow rate, $1.0 \mathrm{~mL} \mathrm{~min}^{-1}$; detection, $254 \mathrm{~nm}$. Enzyme activity was confirmed by determining the amounts of phaseic acid in control experiments before each set of measurements. Inhibition constants were determined using the Enzyme Kinetics module of SigmaPlot 10 software (2006; Systat Software, Inc.) after determining the mode of inhibition by plotting the reaction velocities in the presence and absence of inhibitor on a double-reciprocal plot. For the uninhibited enzymatic reaction, the $K_{\mathrm{M}}$ for (+)-ABA was calculated to be $3.4 \pm 0.6 \mu \mathrm{M}$ based on five separate experiments. All tests were conducted at least two times.

\section{Biological assays}

Rice growth assay. Seeds of rice (Oryza sativa L. cv. Nipponbare) were sterilized with EtOH for 5 min and washed with running tap water. The sterilized seeds were soaked in water and allowed to germinate for 3 days at $25^{\circ} \mathrm{C}$. The seeds were then placed in a glass tube ( $40 \mathrm{~mm}$ i.d.) containing 2 $\mathrm{mL}$ of a test solution and grown with the tube sealed with a plastic cap under continuous light (10000 lux) at $25^{\circ} \mathrm{C}$. When the seedlings were 7 days old, the length of the second leaf sheath was measured, and the inhibition ratio was calculated.

Lettuce growth assays. Five seeds (Lactuca sativa L. cv. Grand Rapids) were placed on two sheets of filter paper soaked in $0.2 \mathrm{ml}$ of a test solution in 24 well plates and allowed to germinate and grow under continuous light for 23 days at $22{ }^{\circ} \mathrm{C}$. 


\section{Selectivity improvement of an azole inhibitor of CYP707A by replacing the monosubstituted azole with a disubstituted azole}

Yasushi Todoroki, ${ }^{\mathrm{a}, *}$ Kumi Naiki, ${ }^{\mathrm{a}}$ Hikaru Aoyama, ${ }^{\mathrm{a}}$ Minaho Shirakura, ${ }^{\mathrm{a}}$ Kotomi Ueno, Masaharu Mizutani, ${ }^{b}$ Nobuhiro Hirai ${ }^{\mathrm{c}}$

${ }^{a}$ Department of Applied Biological Chemistry, Faculty of Agriculture, Shizuoka University, Shizuoka 422-8529, Japan

${ }^{b}$ Graduate School of Agricultural Science, Kobe University, Kobe 657-8501, Japan

${ }^{c}$ Division of Environmental Science and Technology, Graduate School of Agriculture, Kyoto University, Kyoto 606-8501, Japan

Keywords: Plant growth regulator, P450 inhibitor

* Corresponding author. Tel./fax: +81 542384871.

E-mail address: aytodor@agr.shizuoka.ac.jp (Y. Todoroki) 


\begin{abstract}
The plant growth retardant uniconazole (UNI), a triazole inhibitor of gibberellin biosynthetic enzyme (CYP701A), inhibits multiple P450 enzymes including ABA 8'-hydroxylase (CYP707A), a key enzyme in ABA catabolism. Azole P450 inhibitors bind to a P450 active site by both coordinating to the heme-iron atom via $\mathrm{sp}^{2}$ nitrogen and interacting with surrounding protein residues through a lipophilic region. We hypothesized that poor selectivity of UNI may result from adopting a distinct conformation and orientation for different active sites. Based on this hypothesis, we designed and synthesized novel UNI analogues with a disubstituted azole ring (DSI). These analogues were expected to have higher selectivity than UNI because the added functional group may interact with the active site to restrict orientation of the molecule in the active site. DSI-505ME and DSI-505MZ, which have an imidazolyl group with a methyl 5-acrylate, strongly inhibited recombinant CYP707A3, with no growth-retardant effect.
\end{abstract}


Uniconazole is an azole-containing cytochrome P450 inhibitor developed as a plant growth retardant in the $1980 \mathrm{~s} .{ }^{1,2}$ UNI has since been used as a plant growth regulator in agriculture and horticulture. The main site of action of UNI is suggested to be ent-kaurene oxidase (CYP701A), which catalyzes the three-step oxidation of ent-kaurene to ent-kaurenoic acid, $^{3}$ a biosynthetic precursor of the plant hormone gibberellin (GA). This has prompted researchers to use UNI as a chemical tool inhibiting GA biosynthesis. However, UNI also inhibits brassinosteroid biosynthesis ${ }^{4,5}$ and alters the level of other plant hormones, such as auxins, cytokinins, ethylene and abscisic acid (ABA) ${ }^{6}$ Recently, Kitahata et al. ${ }^{7}$ and Saito et al. ${ }^{8}$ revealed that UNI strongly inhibits ABA 8'-hydroxylase $\left(\mathrm{CYP}^{2} 7 \mathrm{~A}^{9,10}\right)$, a key enzyme in ABA catabolism (Figure 1).

Azole-type P450 inhibitors including UNI bind to the target P450 active site by both coordinating to the heme-iron atom and interacting with surrounding protein residues. Because heme coordination is a common property of azole-containing inhibitors, their affinity and specificity for individual P450 enzymes depend on structural properties other than the azole group. UNI may be small and flexible enough to embed itself into various substrate-binding pockets, where UNI may adopt a distinct conformation and orientation for different active sites. Ketoconazole, a well-known antifungal drug, binds to various P450 active sites in different conformations and orientations (Figure 2). In homology models for CYP707A3 and CYP701A3, the active site void spaces that are close to the heme differ in size and shape (Figure 3). Although these models have low reliability because of the low sequence similarity $(\sim 25 \%)$ to template proteins, we speculated that UNI may inhibit various P450 enzymes in a manner similar to the case of ketoconazole. Based on this speculation, in previous works, we generated selective inhibitors of CYP707A by elongating or conformationally freezing the UNI molecule. ${ }^{11,12}$ In this study, we focused on restricting azole orientation by using a disubstituted azole ring for the monosubstituted ring of UNI. A functional group introduced into the azole of UNI can have a new interaction with the active site residues, causing advantageous or disadvantageous reorientation in binding to the active site. This reorientation depends on the active site profile, which will be different for different 
P450 enzymes. We designed and synthesized seven UNI analogues with a disubstituted imidazole (DSI) (Figure 4), which has an oxidized functional group at C2" or C5", in hopes of electrostatic or hydrogen-bonding interactions in addition to steric effects. We checked the enzyme selectivity of the DSI by examining both the inhibitory activity of DSI compounds against recombinant CYP707A and the plant growth retardant effect caused mainly by inhibition of gibberellin biosynthetic enzymes including CYP701A and CYP88A.

DSI-201, DSI-501, and DSI-502 were prepared by a method reported earlier. ${ }^{11}$ Oxidation of DSI-201 with $\mathrm{MnO}_{2}$ gave not the aldehyde but the tautomeric isomer, the cyclic hemiacetal, which was previously reported as a conformationally restricted UNI analogue. ${ }^{11}$ Other disubstituted UNI analogues were synthesized from DSI-501 according to Scheme 1. Methylation and ethylation of DSI-501 with methyl iodide and ethyl iodide, respectively, gave DSI-503 and DSI-504 with 22\% and 89\% yield. DSI-505MZ and DSI-505ME were prepared by a Horner-Emmons reaction of DSI-502 with the phosphonoate. This reaction gave a mixture of $E$ and $Z$ isomers of DSI-505M, DSI-505ME and DSI-505MZ. The major product was the $E$ isomer at room temperature, whereas it was converted into the $Z$-isomer by rising the reaction temperature to $75^{\circ} \mathrm{C}$. The free acid DSI-505 yielded a $E / Z$ mixture (1:2) by partial alkaline hydrolysis during aqueous work-up of the reaction.

The inhibitory activity against ABA 8'-hydroxylase was examined using recombinant Arabidopsis CYP707A3 co-expressed with Arabidopsis P450 reductase (ATR2) in Escherichia coli. ${ }^{12}$ The activity was evaluated based on the decrease in the enzymatic product, phaseic acid, caused by addition of a test compound at a concentration two times higher (10 $\mu \mathrm{M})$ than the substrate $S-(+)-\mathrm{ABA}(5 \mu \mathrm{M}) .{ }^{12}$ For compounds showing $>90 \%$ activity, the inhibition constant $\left(K_{\mathrm{I}}\right)$ was measured. The plant growth-retardant effect was examined using rice seedlings to estimate the concentration giving 50\% inhibition $\left(\mathrm{IC}_{50}\right)$. The results are summarized in Table 1.

DSI-201 was much less effective in both assays. This compound is substituted at C2" adjacent to N3", which actually coordinates to the heme iron. The C2" hydroxymethyl group may interfere with N-Fe coordination. DSI-501, DSI-502, and DSI-503 were less effective 
than UNI by a factor of 20-50 in both assays. The hydroxymethyl, formyl, and methoxymethyl groups at C5" may have a similar unfavorable effect on binding to the active sites of CYP707A and CYPs involved in plant growth. DSI-504, with the C5" ethoxymethyl group, was less effective than DSI-501, DSI-502, and DSI-503 in both assays. This may be because of the larger steric effect by substituents at both C5" and C3. DSI-505MZ and DSI-505ME exhibited CYP707A inhibitory activity equivalent to that of DSI-501, DSI-502, and DSI-503 in spite of its larger C5" substituent, whereas it had little inhibitory activity on rice seedling growth. This suggests that the methyl acrylate moiety at $\mathrm{C} 5$ " is tolerated in the CYP707A active site, but not in those of CYPs involved in plant growth. Considering that DSI-505MZ and DSI-505ME were less effective CYP707A inhibitors than UNI and the inhibitory potency was largely independent of the acrylate E/Z geometry, the acrylate at C5" may function as a steric obstacle, and neither an electrostatic nor a hydrogen-bonding donor or acceptor, for the amino acid residues in the active site; its sterically unfavorable effect may be too small for CYP707A to allow the inhibitor azole to orient to the heme iron, but too large for CYPs involved in plant growth to allow it. On the other hand, the free acid DSI-505 (E/Z mixture) exhibited little inhibitory activity in either assay. Because the P450 active site is generally hydrophobic, the carboxylate may not be accepted. We cannot discuss the structure-activity relationships in greater detail due to the lack of structural characterization of CYP707A and the CYPs involved in plant growth.

We tested the effect of DSI-505ME on early growth of lettuce in the presence and absence of ABA. DSI-505ME exhibited no significant effect at the tested concentrations of 0.1 to 100 $\mu \mathrm{M}$, whereas it enhanced the effect of $10 \mu \mathrm{M}$ ABA upon simultaneous application of $100 \mu \mathrm{M}$ inhibitor (Figure 5). This suggests that DSI-505ME acts as an inhibitor of CYP707A in vivo as well as in vitro to keep a high concentration of ABA.

Finally, we found a more selective azole inhibitor than UNI by replacing the monosubstituted azole with the disubstituted one. This design strategy may be useful for increasing the selectivity of azole CYP inhibitors. 


\section{Acknowledgments}

We thank Toray Industries Inc., Tokyo, Japan, for the gift of (+)-ABA. Part of this research was carried out using an instrument at the Center for Instrumental Analysis of Shizuoka University. This research was supported by a Grant-in-Aid for Scientific Research (No. 22580118) from the Ministry of Education, Culture, Sports, Science and Technology of Japan.

\section{Supplementary data}

The synthetic procedure for new compounds, their ${ }^{1} \mathrm{H}$ NMR and high-resolution MS data, and the procedures for homology modeling, enzyme assay, and biological assays are given. Supplementary data associated with this article can be found in the online version at doi:xx.xxxx/j.bmcl.2010.xx.xxx.

\section{References and notes}

1. Funaki, Y.; Ishiguri, T.; Kato, T.; Tanaka, S. J. Pesticide Sci. 1984, 9, 229.

2. Funaki, Y.; Oshita, H.; Yamamoto, S.; Tanaka, S.; Kato, T. (Sumitomo Chemical Co.). Ger. Offen. DE3010560, 1980.

3. Izumi, K.; Kamiya, Y.; Sakurai, A.; Oshio, H.; Takahashi, N. Plant Cell Physiol. 1985, 26,821 .

4. Iwasaki, T.; Shibaoka, H. Plant Cell Physiol. 1991, 32, 1007.

5. Asami, T.; Mizutani, M.; Fujioka, S.; Goda, H.; Min, Y. K.; Shimada, Y.; Nakano, T.; Takatsuto, S.; Matsuyama, T.; Nagata, N.; Sakata, K.; Yoshida, S. J. Biol. Chem. 2001, 276, 25687. 
6. Izumi, K.; Nakagawa, S.; Kobayashi, M.; Oshio, H.; Sakurai, A.; Takahashi, N. Plant Cell Physiol. 1988, 29, 97.

7. Kitahata, N.; Saito, S.; Miyazawa, Y.; Umezawa, T.; Shimada, Y.; Min, Y. K.; Mizutani, M.; Hirai, N.; Shinozaki, K.; Yoshida, S.; Asami, T. Bioorg. Med. Chem. 2005, 13, 4491.

8. $\quad$ Saito, S.; Okamoto, M.; Shinoda, S.; Kushiro, T.; Koshiba, T.; Kamiya, Y.; Hirai, N.; Todoroki, Y.; Sakata, K.; Nambara, E.; Mizutani, M. Biosci. Biotechnol. Biochem. 2006, 70, 1731.

9. Saito, S.; Hirai, N.; Matsumoto, C.; Ohigashi, H.; Ohta, D.; Sakata, K.; Mizutani, M. Plant Physiol. 2004, 134, 1439.

10. Kushiro, T.; Okamoto, M.; Nakabayashi, K.; Yamagishi, K.; Kitamura, S.; Asami, T.; Hirai, N.; Koshiba, T.; Kamiya, Y.; Nambara, E. ENBO J. 2004, 23, 1647.

11. Todoroki, Y.; Kobayashi, K.; Shirakura, M.; Aoyama, H.; Takatori, K.; Nimitkeatkai, H.; Jin, M.-H.; Hiramatsu, S.; Ueno, K.; Kondo, S.; Mizutani, M.; Hirai, N. Bioorg. Med. Chem. 2009, 17, 6620.

12. Todoroki, Y.; Aoyama, H.; Hiramatsu, S.; Shirakura, M.; Nimitkeatkai, H.; Kondo, S.; Ueno, K.; Mizutani, M.; Hirai, N. Bioorg. Med. Chem. Lett. 2009, 19, 5782.

13. Todoroki, Y.; Kobayashi, K.; Yoneyama, H.; Hiramatsu, S.; Jin, M.-H.; Watanabe, B.; Mizutani, M., Hirai, N. Bioorg. Med. Chem. 2008, 16, 3141. 
Figure and Scheme legends

Figure 1. UNI is a potent inhibitor of ABA 8'-hydroxylase (CYP707A) and ent-kaurene oxidase (CYP701A).

Figure 2. Overlaid structures of ketoconazole-binding P450 active sites: black, 3LD6 (human CYP51); pink, 2V0M (human CYP3A4); blue, 1JIN (bacterial CYP107A1); green, 2JJP (bacterial CYP113A1). The figures were manually drawn using Chimera after automatic overlay.

Figure 3. Ligand binding sites in the homology models of CYP707A3 (top) and CYP701A3 (bottom). Molecular surfaces were calculated and displayed with PyMOL.

Figure 4. Chemical structures of DSI.

Figure 5. Enhanced effect of DSI-505ME on ABA activity in an early growth assay of lettuce.

Scheme 1. Synthesis of DSI. Reagents and conditions: (i) $\mathrm{NaH}, \mathrm{MeI}, \mathrm{DMF}, 0^{\circ} \mathrm{C}, 22 \%$; (ii) $\mathrm{NaH}$, EtI, DMF, $0^{\circ} \mathrm{C}, 89 \%$; (iii) $\mathrm{NaH},\left(\mathrm{CF}_{3} \mathrm{CH}_{2} \mathrm{O}\right)_{2} \mathrm{P}(\mathrm{O}) \mathrm{CH}_{2} \mathrm{CO}_{2} \mathrm{Me}$, THF, $0 \rightarrow 75^{\circ} \mathrm{C}, 8 \%$ (DSI-505MZ) and trace (DSI-505); (iv) $\mathrm{NaH},\left(\mathrm{CF}_{3} \mathrm{CH}_{2} \mathrm{O}\right){ }_{2} \mathrm{P}(\mathrm{O}) \mathrm{CH}_{2} \mathrm{CO}_{2} \mathrm{Me}, \mathrm{THF}, 0^{\circ} \mathrm{C}$ $\rightarrow \mathrm{rt}, 32 \%(\mathrm{DSI}-505 \mathrm{ME})$ and $6 \%(\mathrm{DSI}-505)$. 


\section{Table 1}

Inhibitory activity of DSI against recombinant CYP707A3 and rice seedling elongation. The values are averages of two independent experiments.

\begin{tabular}{|c|c|c|c|c|c|}
\hline \multirow{2}{*}{ Compound } & \multicolumn{2}{|c|}{ Structural properties } & \multicolumn{2}{|l|}{ CYP707A3 } & \multirow{2}{*}{$\begin{array}{l}\text { Rice growth } \\
\mathrm{IC}_{50}(\mu \mathrm{M})\end{array}$} \\
\hline & $2-\mathbf{A z}$ & $3-\mathrm{OX}$ & Inhibition $^{c}(\%)$ & $K_{\mathrm{I}}(\mathrm{nM})$ & \\
\hline $\mathrm{UNI}^{\mathrm{a}}$ & & $\mathrm{H}$ & 100 & 10 & 0.18 \\
\hline $\mathrm{IMI}^{\mathrm{b}}$ & & $\mathrm{H}$ & 100 & 0.6 & 2.3 \\
\hline DSI-201 & & $\mathrm{H}$ & 31 & $-{ }^{\mathrm{d}}$ & $>100$ \\
\hline DSI-501 & & $\mathrm{H}$ & 95 & 160 & 5.4 \\
\hline DSI-502 & & $\mathrm{H}$ & 91 & 240 & 10 \\
\hline DSI-503 & & $\mathrm{CH}_{3}$ & 95 & 190 & 9.6 \\
\hline DSI-504 & & $\mathrm{C}_{2} \mathrm{H}_{5}$ & 62 & - & 32 \\
\hline DSI-505MZ & & $\mathrm{H}$ & 98 & 220 & $>100$ \\
\hline DSI-505ME & & $\mathrm{H}$ & 100 & 120 & $>100$ \\
\hline DSI-505 & & $\mathrm{H}$ & 31 & - & $>100$ \\
\hline
\end{tabular}

\footnotetext{
${ }^{a}$ Ref. 11

${ }^{b}$ Ref. 13

${ }^{\mathrm{c}}$ Inhibition ratio of compounds $(10 \mu \mathrm{M})$ in the 8'-hydroxylation of ABA $(5 \mu \mathrm{M})$

${ }^{\mathrm{d}}$ Not measured
} 


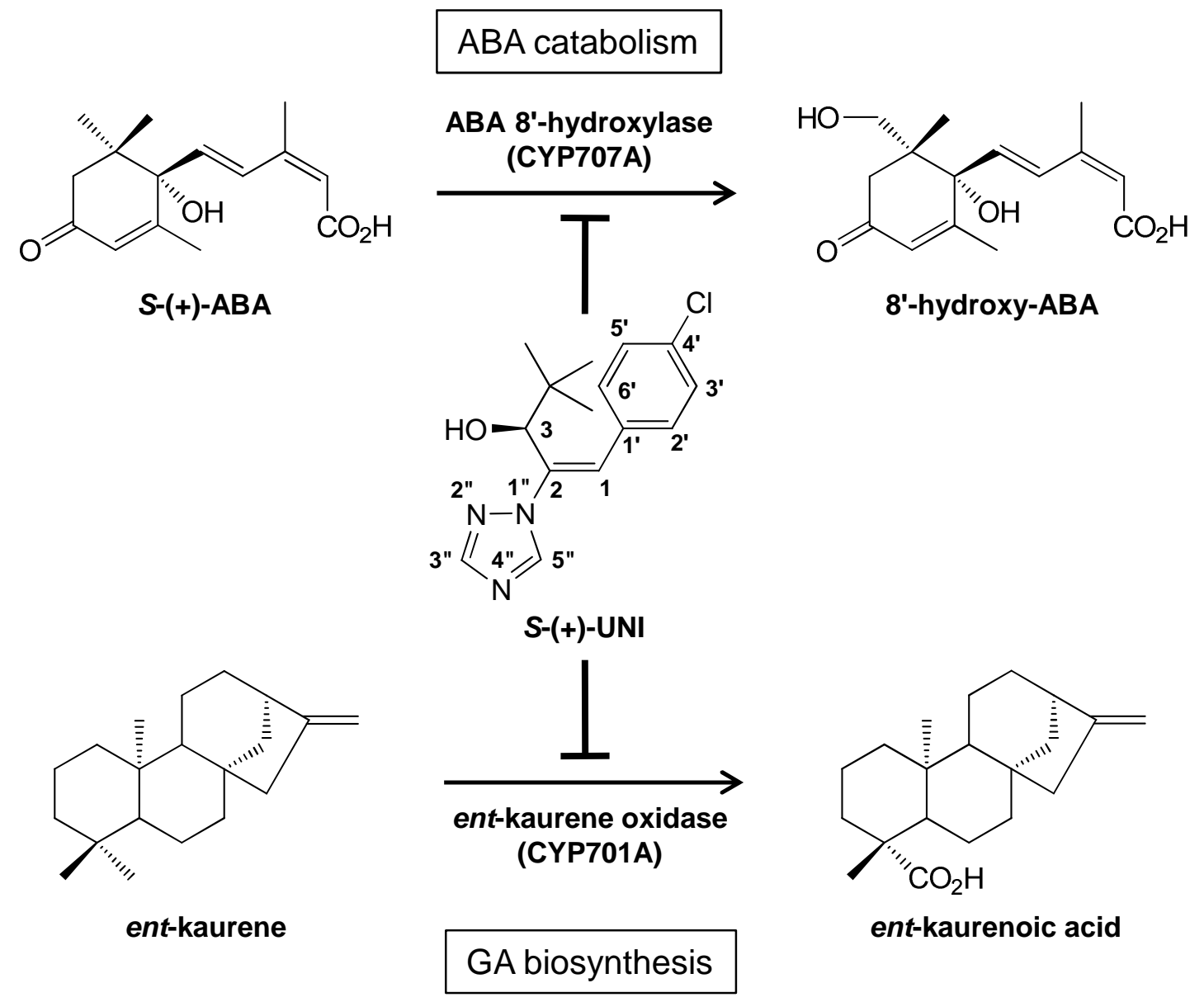

Figure 1 


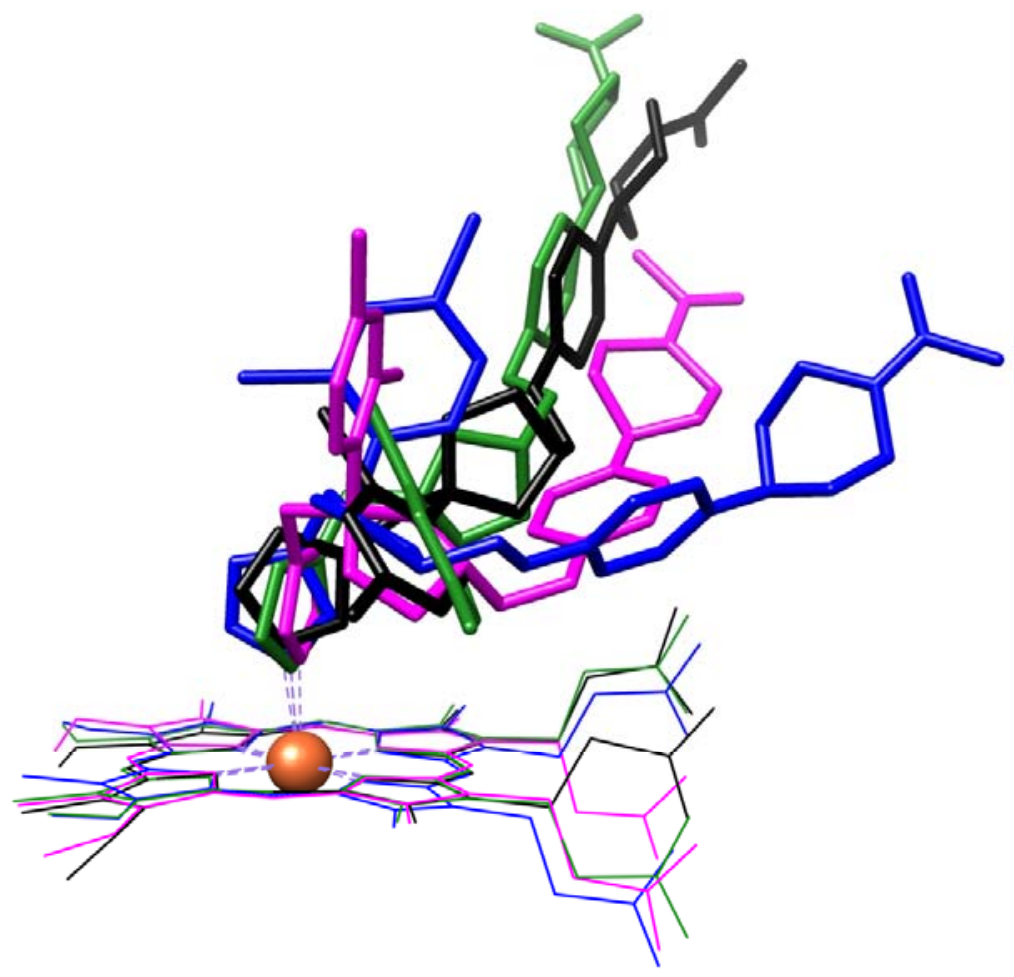

Figure 2 

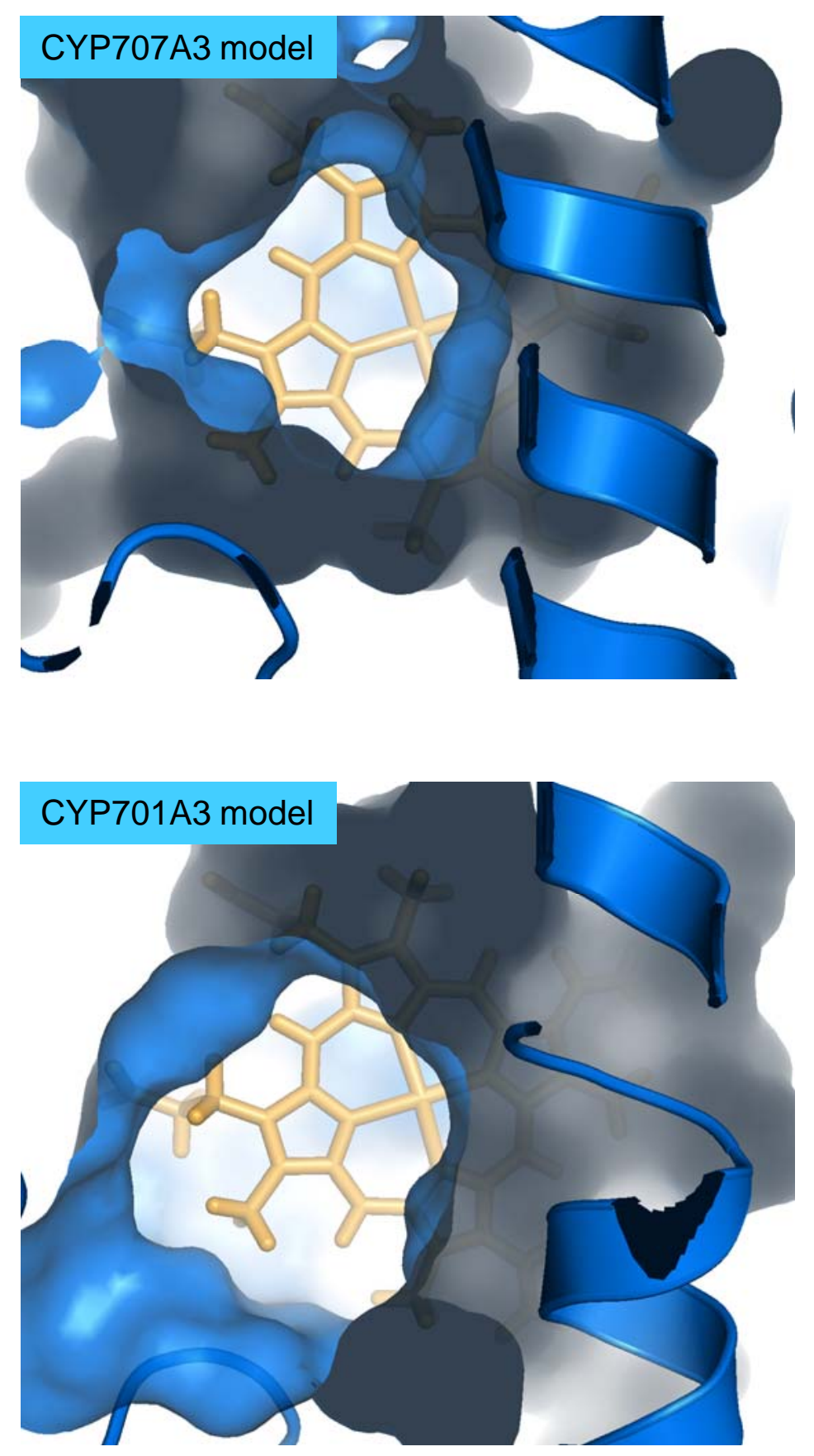

Figure 3 


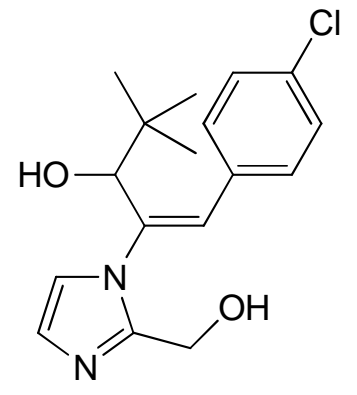

DSI-201

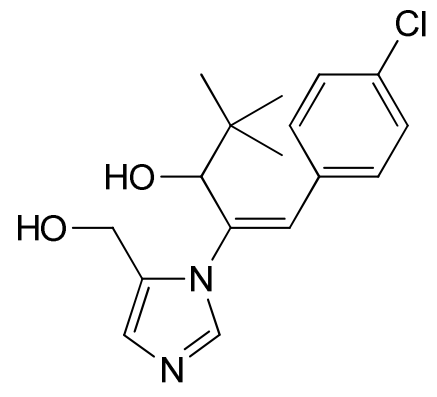

DSI-501

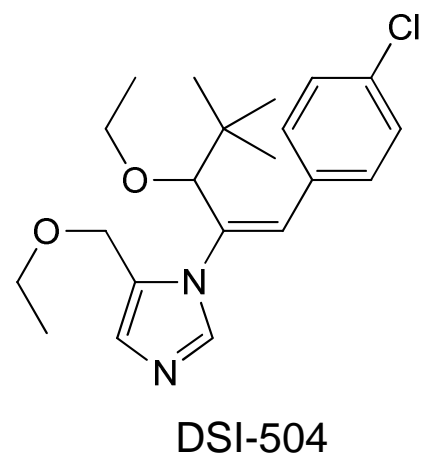

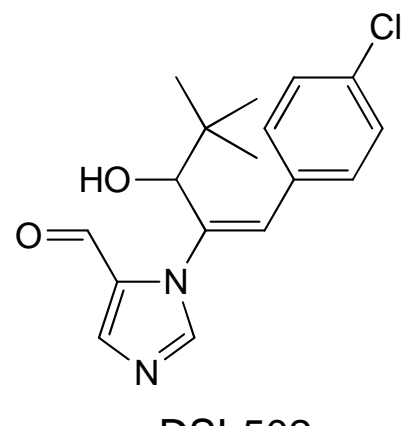

DSI-502

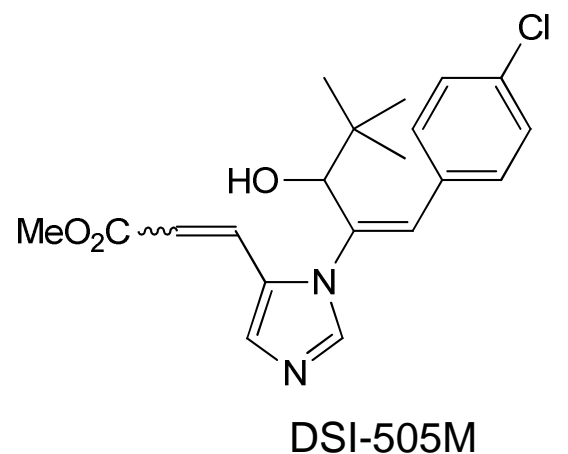

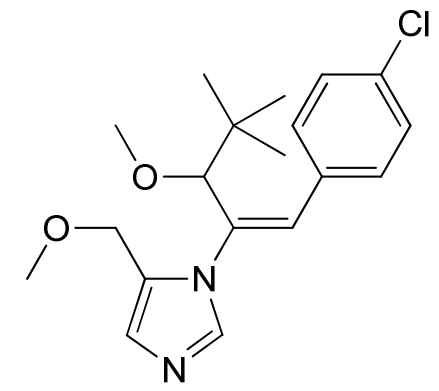

DSI-503

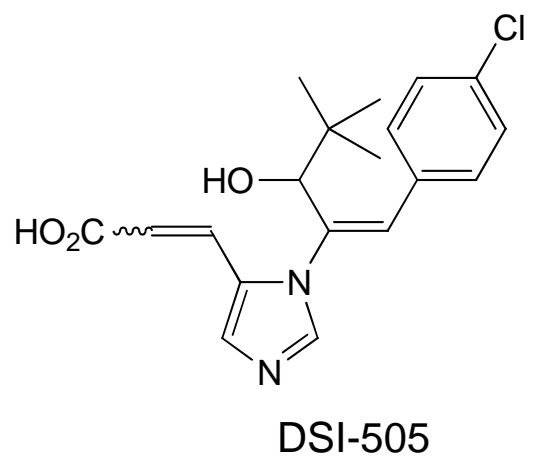

Figure 4 


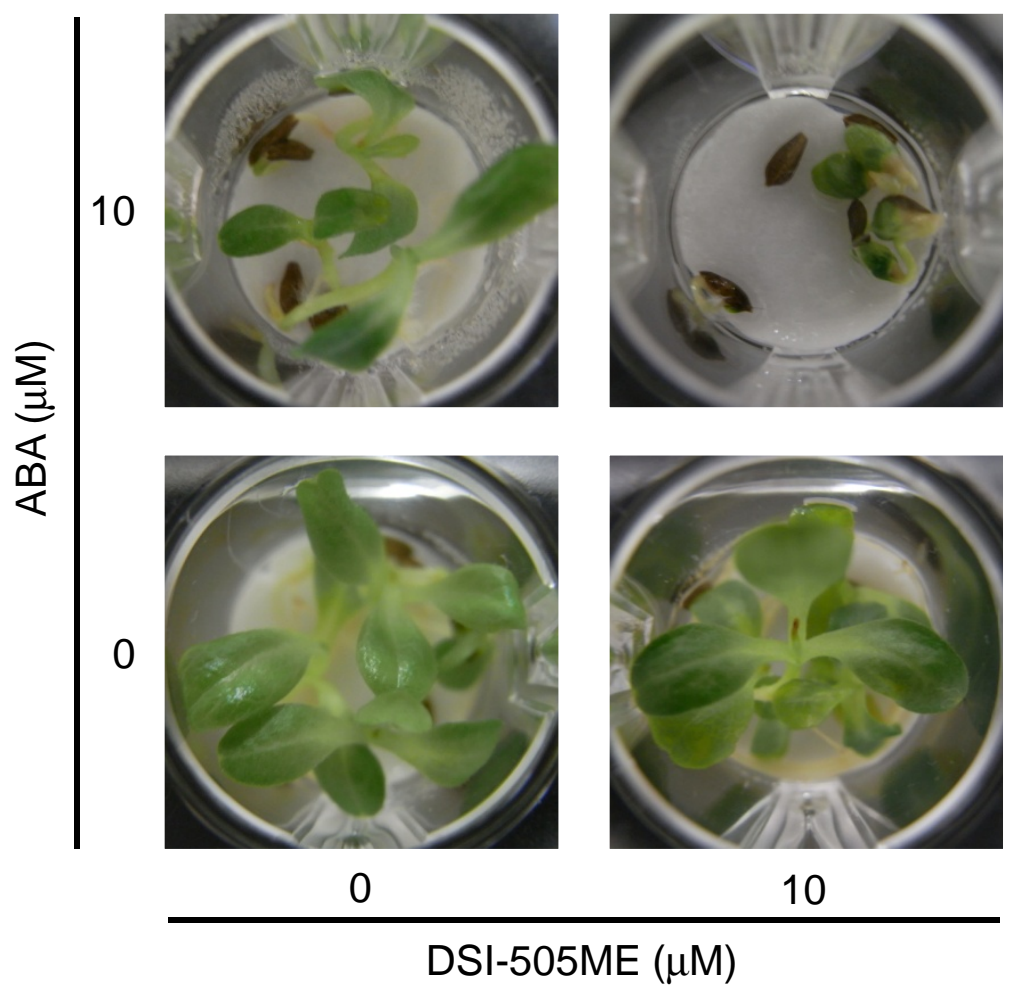

Figure 5 


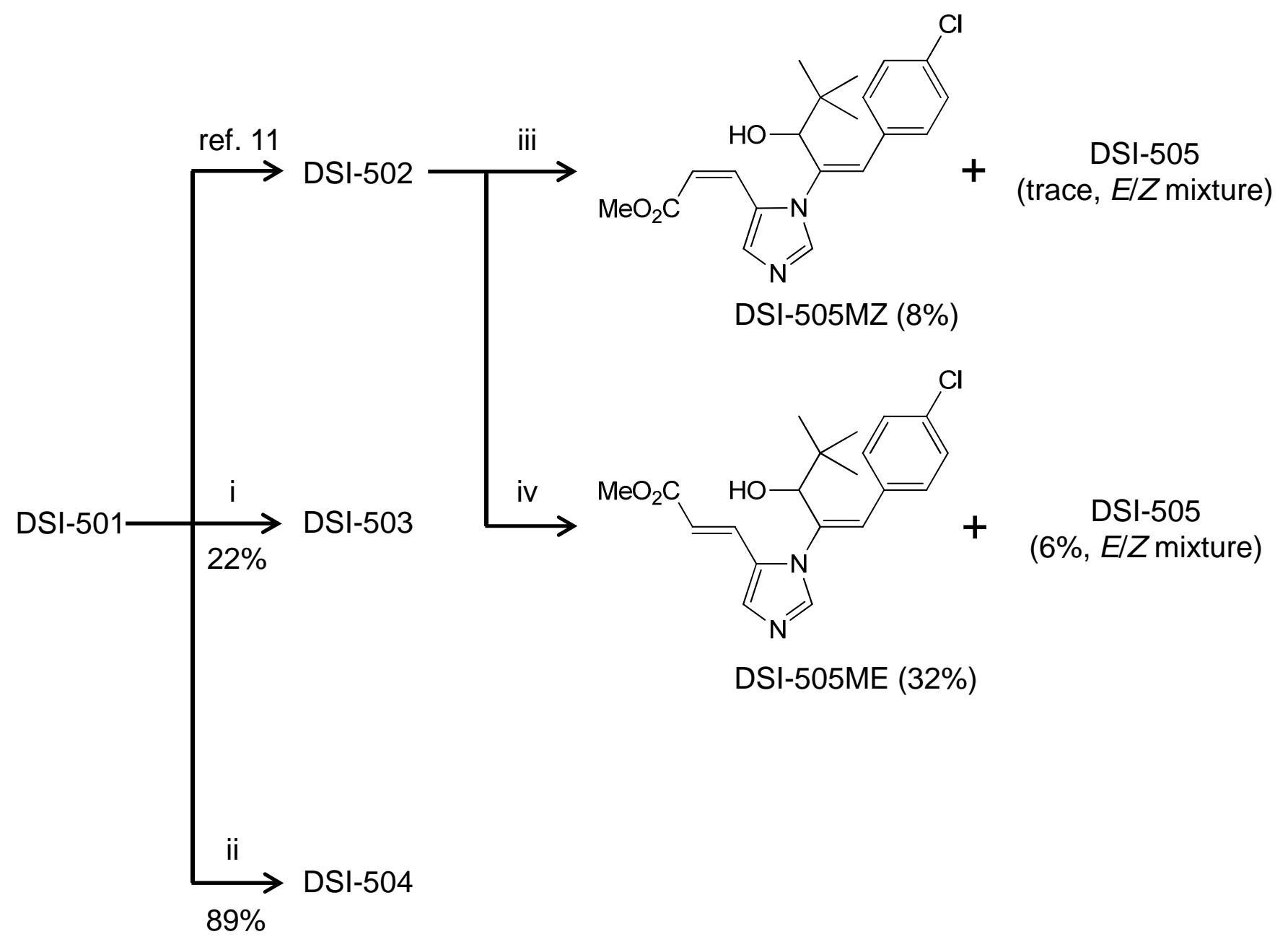

Scheme 1 